\title{
Isolation of dengue 2 virus from a patient with central nervous system involvement (transverse myelitis)
}

\author{
Isolamento de dengue 2 de paciente com comprometimento \\ do sistema nervoso central (mielite transversa)
}

\author{
Raimundo N.Q. Leão1, Teichi Oikawa², Elizabeth S.T. Rosa ${ }^{3}$, José T. Yamaki ${ }^{4}$, Sueli G. Rodrigues ${ }^{3}$, \\ Helena B. Vasconcelos ${ }^{3}$, Maria R.S. Sousa ${ }^{3}$, Jaime K. Tsukimata ${ }^{4}$, \\ Raimunda S.S. Azevedo ${ }^{3}$ and Pedro F.C. Vasconcelos ${ }^{3}$
}

\begin{abstract}
A dengue fever case is described in a 58-year-old male patient with febrile illness and thrombocytopenia complicated by neurological involvement characterized by transverse myelitis followed by weakness of both legs and flaccid paralysis. Muscle strength was much diminished and bilateral areflexia was observed. Dengue 2 (DEN-2) virus was isolated and the patient sero-converted by hemagglutination-inhibition and IgM-ELISA tests. The RT-PCR test was positive to DEN-2 in acute phase serum and culture supernatant, but negative in the cerebrospinal fluid. After three weeks of hospitalization the patient was discharged. No other infectious agent was detected in the blood and cerebrospinal fluid samples. The patient had full recovery from paralysis six months after the onset of DEN-2 infection.
\end{abstract}

Key-words: Dengue fever. Transverse myelitis. Dengue 2. Virus isolation. RT-PCR.

Resumo Um caso de febre clássica de dengue é descrito em paciente masculino de 58 anos de idade que desenvolveu quadro febril acompanhado de trombocitopenia complicado com envolvimento neurológico caracterizado por mielite transversa, a qual se seguiu de fraqueza de ambos os membros inferiores e paralisia flácida. A força muscular do paciente ficou bastante diminuída e arreflexia bilateral também foi observada. $O$ sorotipo dengue 2 (DEN-2) foi isolado e o paciente também soro-converteu em testes de inibição de hemaglutinação e IgM-ELISA. Da mesma amostra de soro da fase aguda da qual o vírus foi isolado, teste de $R T-P C R$ foi positivo para DEN-2. RT-PCR foi igualmente positivo utilizando o sobrenadante da cultura positiva, mas foi negativo usando-se o líquido cefalo-raquidiano (LCR) obtido com 12 dias de doença. Nenhum outro agente infeccioso foi isolado ou identificado em testes sorológicos utilizando as amostras séricas e o LCR. O paciente foi hospitalizado por três semanas, tendo recebido alta do quadro de dengue ainda com problemas da paralisia que foi sanada após seis meses do início da infeção pelo DEN-2.

Palavras-chaves: Febre clássica do dengue. Mielite transversa. Dengue 2. Isolamento viral. RT-PCR.

Dengue fever (DF) and dengue hemorrhagic fever (DHF) are caused by dengue (DEN) virus serotypes 1 to 4 , transmitted by bites of Aedes aegypti mosquitoes, and represent important infectious diseases in tropical and subtropical countries ${ }^{423}$. In Brazil, from 1986 through 1999, more than one million and a half cases have been reported ${ }^{23}$. Few cases of DHF have been diagnosed, and the serotypes DEN-1 and DEN-2 have been responsible for epidemics in the whole country, including the city of Belém ${ }^{1623}$ from which the case reported here came. This case is an unusual presentation of DF with neurological complications, caused by dengue 2 virus.

\footnotetext{
1. Departamento de Saúde Comunitária da Universidade do Estado do Pará, Belém, PA, Brazil; 2. Departamento de Clínica Médica da Universidade Federal do Pará, Belém, PA, Brazil; 3. Seção de Arbovírus, World Health Organization Collaborating Center for Arbovirus Reference and Research, Instituto Evandro Chagas da Fundação Nacional de Saúde do Ministério da Saúde, Belém, PA, Brazil; 4. Hospital Amazônia, Belém, PA, Brazil. Supported by Instituto Evandro Chagas, FUNASA, Ministry of Health of Brazil.

Address to: Dr. Pedro Fernando da Costa Vasconcelos. Seção de Arbovírus/IEC/FUNASA. Av. Almirante Barroso 492, $66090-000$ Belém, PA, Brazil. Tel.: 5591 211-4409; Fax: 5591 226-1284

Recebido para publicação em 2/7/2001.
} 


\section{CASE REPORT}

The patient, a 58-year-old man, born in Japan and living in Belém, Brazil, for 10 months, presented for medical consultation with a history of febrile illness for three days. When seen (18 ${ }^{\text {th }}$ January 2000$)$, the symptoms were fever of sudden onset, weakness and malaise for three days, accompanied in the last two days by mild headache, diarrhea and rash on the legs and arms. During the interview, the patient gave a history of moderate use of alcohol, bilateral occurrence of renal lithiasis, angina pectoris, a transient cerebrovascular ischemic stroke in 1995, and diverticulosis in 1999. On examination he appeared mildly ill, and reported nasal and gingival hemorrhages. An erythematous fine pruriginous macular rash was observed on the arms and legs, where several petechiae were also detected. No tenderness was found in the abdomen, costovertebral angles or spines. Neurologic examination was negative, the extremities were perfusing, and the axillary temperature reached $38^{\circ} \mathrm{C}$.

Specimens of blood were obtained and showed: leucogram $2,800 / \mathrm{mm}^{3}$, lymphocytes $25 \%$, platelets $60,000 / \mathrm{mm}^{3}$, ALT: $66 \mathrm{U} / \mathrm{mm}^{3}$ and AST: $99 \mathrm{U} / \mathrm{mm}^{3}$. From this serum sample virus isolation was attempted. The presumptive diagnosis was dengue fever (DF) with reduction of platelets, and the patient was sent home.
Two days later $\left(20^{\text {th }}\right.$ January, 2000) he returned with fever, muscle pains, anorexia, reporting acute urinary retention, and although the leukocyte count had returned to normal values $\left(6,100\right.$ cells $\left./ \mathrm{mm}^{3}\right)$, he was admitted.

On admission, a Foley's bladder probe was used and an evaluation by an urologist was made that did not find alterations. Blood samples were taken for biochemical examination (Table 1). Blood and urine cultures were also performed. The platelets were $50,000 / \mathrm{mm}^{3}$ and leuckocytes remain normal, but aminotransferases were still showing a slight increase (Table 1), but the patient felt much improved and physical examination was unchanged. On $24^{\text {th }}$ January ( $9^{\text {th }}$ day after onset) the platelet count remained low but was showing a discrete increase reaching to $116,000 / \mathrm{mm}^{3}$, and g-GT was highly increased (Table 1). Clinically the patient exhibited sleepiness and confusion in answering verbal inquiries, but the fever improved and the rash was slowly fading. Cardiologic evaluation was done, and apparently good conditions were observed excluding the possibility of myocarditis. The patient exhibited difficulties in walking and answering questions, and had cough, malaise, and hiccups. Chest X-ray was normal. On the next day, 25 January $\left(10^{\text {th }}\right.$ day of disease), the patient showed a better disposition and accepted oral nutrition.

\begin{tabular}{|c|c|c|c|c|c|c|c|c|}
\hline Exams & 18 Jan & 20 Jan & 22 Jan & 24 Jan & 27 Jan & 29 Jan & $8 \mathrm{Feb}$ & Reference value \\
\hline Leukocytes & 2,800 & 6,300 & 9,100 & 9,500 & 18,000 & 8,600 & 7,500 & $5-10 \times 10^{3} / \mathrm{mm}^{3}$ \\
\hline eosino & 3 & 2 & 2 & - & 3 & 2 & 3 & $2-4 \%$ \\
\hline mono & 3 & 2 & 7 & 4 & 2 & 3 & 3 & $4-8 \%$ \\
\hline neut & 69 & 74 & 70 & 54 & 82 & 69 & 69 & $36-65 \%$ \\
\hline bands & - & - & - & - & 2 & - & - & $0-5 \%$ \\
\hline lympho & 25 & 22 & 21 & 42 & 11 & 26 & 25 & $25-44 \%$ \\
\hline Platelets & 60,000 & 50,0000 & 60,000 & 116,000 & 160,000 & 204,000 & 230,000 & $150-450 \times 10^{3} / \mathrm{mm}^{3}$ \\
\hline Hematocrit & $43 \%$ & $47 \%$ & $45 \%$ & $42 \%$ & $45 \%$ & $45 \%$ & $41 \%$ & $42-47 \%$ \\
\hline ALT & 66 & 123 & - & 80 & 62 & 79 & 47 & $10-34 \mathrm{U} / \mathrm{dl}$ \\
\hline AST & 99 & 199 & - & 82 & 94 & 49 & 28 & $9-43 \mathrm{U} / \mathrm{dl}$ \\
\hline Urea & 15 & 16 & - & 25 & 33 & 34 & - & $15-40 \mathrm{mg} / \mathrm{dl}$ \\
\hline Creatinine & 1.2 & 1.1 & - & 0.9 & 1.0 & 0.9 & - & $0.4-1.3 \mathrm{mg} / \mathrm{dl}$ \\
\hline Bilirubin & - & 0.5 & - & - & 1.3 & - & - & $0.2-1.0 \mathrm{mg} / \mathrm{dl}$ \\
\hline direct & - & 0.3 & - & - & 0.3 & - & - & $0.05-0.3 \mathrm{mg} / \mathrm{dl}$ \\
\hline Glycemia & 104 & 105 & - & 144 & 126 & 140 & 100 & $70-110 \mathrm{mg} / \mathrm{dl}$ \\
\hline$\gamma$-GT & - & - & - & 745 & 423 & - & 233 & $7-45 \mathrm{U} / \mathrm{I}$ \\
\hline Hemoculture & - & negative & negative & negative & negative & - & - & - \\
\hline
\end{tabular}

- Not found or not performed

Two days later, $27^{\text {th }}$ January ( $12^{\text {th }}$ day after onset), flaccid paraparesis was observed, the fever returned and leukocytes reached $18,000 / \mathrm{mm}^{3}$ ( $84 \%$ neutrophils). Cerebrospinal fluid (CSF) showed $21 \mathrm{cells} / \mathrm{mm}^{3}(100 \%$ mononuclear cells), a slight increase of protein $(89 \mathrm{mg} /$ $\mathrm{dL}$ ), but chlorides and glucose had normal values. A CT scan (brain, column and chest) showed bilateral pneumonia, while magnetic resonance of CNS did not detect abnormalities. Ceftriaxone was used. From 28
January through 6 February clinical examination was unchanged. On $7^{\text {th }}$ February the patient reported diminution in the field of vision, especially in the right eye, and on ophthalmologic examination chorioretinitis was diagnosed compatible with residual toxoplasmosis.

DEN-2 virus was isolated in C6/36 cells from the blood obtained on 19 January. Serology for dengue in paired samples showed serologic conversion [acute sample negative (collection on $18^{\text {th }}$ January) and 
convalescent positive (obtained on $25^{\text {th }}$ January) for lgMELISA ${ }^{7}$; by $\mathrm{HI}^{19}$ titres were $<1: 20$ in acute and $>1: 1280$ [secondary response for all flaviviruses tested (DEN-1, DEN2, DEN-3, DEN-4, yellow fever, Ilheus, Rocio and Saint Louis Encephalitis viruses)], and negative in both samples for alphaviruses (Eastern Equine, Western Equine and Venezuelan Equine (Subtype III - Mucambo) encephalitis, and Mayaro viruses), and bunyaviruses (Oropouche, Tacaiuma, Guaroa, Caraparu, Catu and Maguari viruses). The CSF test was negative for dengue, syphilis, cysticercosis, and toxosplamosis, as well as cultures for bacteria, mycosis and viruses. RNA was detected by RT$\mathrm{PCR}^{9}$ to DEN-2 from acute phase serum and from culture supernatants, but was negative in the CSF.

Other specific exams (for differential diagnosis) were carried out from blood collected on different days of the disease and showed the following results: Serology IgM-ELISA were negative to toxoplasmosis (IgG positive), CMV (IgG positive), EBV and other herpes viruses (IgG negative), rubella (IgG positive), HIV (IgG negative), HTLV I (IgG negative), HTLV II (IgG negative), HAV (anti HAV IgM) HBV (HbsAg and anti HBc IgM), and HCV (anti HCV IgM). Hemoculture (three samples) was negative, and culture of urine (two samples) was also negative. Exams for systemic lupus erythematosus (antinuclear factor, anti DNA antibodies, SSB/LA, SM and SSA/RO) were negative.

The patient was discharged on $23^{\text {rd }}$ February with a diagnosis of DF complicated by flaccid paralysis and reduction of vision, and pneumonia secondary to DF. About six months later, the patient had full recovery from the paralysis.

\section{DISCUSSION}

Dengue viruses have been striking the inhabitants of Belém from 1996 to date ${ }^{16}$. The occurrence of cases increases annually during the rainy season that occurs between December and May. The case reported occurred in January, when the rains are daily, and the vector population (Aedes aegypti) increases.

The DEN-2 serotype was isolated from a blood sample and RNA of the virus was recovered from acute phase serum and from culture supernatants by RT-PCR. Moreover, serologic conversion to flaviviruses was obtained. Thus, the etiology of the illness was the DEN2 virus. The question is if the neurological involvement reported in the case was DEN-2 associated or if it resulted from metabolic alterations.

The pathogenesis of DHF and DF is complicated and still little understood ${ }^{20}$. The main hypotheses ${ }^{617}$ are not compatible for neurological involvement, and cases with central nervous system (CNS) involvement are generically included as dengue with unusual manifestations ${ }^{1213}$.

Thus, the occurrence of neurological complications during dengue infections is debatable and not well understood. Frequently dengue infection has been associated with encephalopathy followed by shock and hypoxemia of CNS 3101417182122 , but articles published elsewhere have shown that in some cases the criteria for breakdown of the blood-brain barrier of the CNS have been fulfilled ${ }^{1} 23111^{14}$. Effectively, Lum et $\mathrm{al}^{10}$, have supported the hypothesis of the occurrence of a true encephalitis caused by dengue viruses, and Ramos et $\mathrm{al}^{14}$, have detected antigen by immunohistochemistry and DEN-4 RNA in neurons, astrocytes, microglia and endothelial cells. Previously, Chimelli et $\mathrm{al}^{1}$ published five fatal dengue cases with neurological involvement, showing neuropathological lesions including perivenous leukoencephalitis, and more recently Miagostovich et al ${ }^{11}$ found dengue virus antigens in Virchow Robin space, both articles support or point to the hypothesis that dengue viruses can infect the CNS.

The patient in question, a middle-aged man with personal history of alcoholism, had problems of the cardiovascular and cerebral systems, and ocular toxoplasmosis. It is possible that these antecedents increased his susceptibility to, or facilitated, the CNS involvement.

In the present case, the severe paralysis of both limb members is intriguing. Only three months after the infection, the patient recovered first the muscle sensation and then began to become capable of walking, and full recovery, including walking, was only observed six months after onset of the infection. Blood screening performed with (one acute and two convalescent) and CSF samples covering the most important infectious agents associated with CNS involvement including HIV, HTLV I, HTLV II, CMV, EBV, HBV, HCV, and toxoplasmosis were negative, as well as systemic lupus erythemathosus. Thus, we presume that the clinical pictures presented were DEN-2 virus associated. Further molecular studies ${ }^{15}$ may be carried out soon in order to characterize the genotype of this DEN-2 strain.

Finally, it is important to remember that the patient had acute diminution of visual acuity, considered to be associated to the ocular toxoplasmosis previously mentioned by the patient. Thus, they were not considered to be a consequence of dengue and were therefore omitted in this report.

\section{ACKNOWLEDGEMENTS}

We thank Dr. Alexandre Linhares and Dr. Manoel Soares of the Department of General Virology at Instituto Evandro Chagas for performance of exams for differential diagnosis, Dr. Yuji Ikuta, of the Hospital Amazônia, for administrative support during the illness of the patient, and Dr. Jack Woodall of the Universidade Federal do Rio de Janeiro for critical reading of the manuscript 


\section{REFERENCES}

1. Chimelli L, Dumas Hahn M, Barretto Netto M, Ramos RG, Dias M, Gray F. Dengue: neuropathological findings in 5 fatal cases from Brazil. Clinical Neuropathology 9:157-162, 1990.

2. Cordeiro MT. Dengue in the state of Pernambuco, Brazil; 19951997. Virological, clinical and epidemiological aspects. Virus Review and Research 2:112-113, 1997.

3. Cunha RV, Schatzmayr HG, Miagostovich MP, Barbosa AMA, Paiva FG, Miranda RMO, Ramos CCF, Coelho JCO, Santos FB, Nogueira RMR. Dengue in the State of Rio Grande do Norte. Transactions of the Royal Society of Tropical Medicine and Hygiene 93:247-249, 1999.

4. George R, Lum LCS. Clinical spectrum of dengue infection. In: Gubler DJ, Kuno G (eds) Dengue and dengue hemorrhagic fever. London, Cab International 89-113,1997.

5. Gubler DJ. Dengue and dengue hemorrhagic fever. Clinical Microbiology Reviews 13:480-496, 1998.

6. Halstead SB. Pathogenesis of dengue. Challenges to molecular biology. Science 239:476-481, 1988.

7. Kuno G, Gomez I, Gubler DJ. Detecting artificial antidengue IgM complexes using an enzyme-linked immunosorbent assay. American Journal of Tropical Medicine and Hygiene 36:153-9, 1987.

8. Kurane I, Ennis FA. Immunopathogenesis of dengue virus infections. In: Gubler DJ, Kuno G (eds) Dengue and dengue hemorrhagic fever. London: Cab International 273-290,1997.

9. Lanciotti RS, Calisher CH, Gubler DJ, Chang GJ, Vorndam AV. Rapid detection and typing of dengue viruses from clinical samples by using reverse transcriptase-polymerase chain reaction. Journal of Clinical Microbiology 30:545-551, 1992.

10. Lum LC, Lam SK, Choy YS, George R, Harun F. Dengue encephalitis: a true entity? American Journal of Tropical Medicine and Hygiene 54:256-259, 1996.

11. Miagostovich MP, Ramos RG, Nicol AF, Nogueira RM, CuzziMaya T, Oliveira AV, Marchevsky RS, Mesquita RP, Schatzmayr HG. Retrospective study of dengue fatal cases. Clinical Neuropathology 16:204-208, 1997.

12. Nimmannitya $S$, Thisyakorn $U$, Hemsrichart $Y$. Dengue haemorrhagic fever with unusual manifestations. Southeast Asian Journal of Tropical Medicine and Public Health 18:398406, 1987.

13. Patey O, Ollivaud L, Breuil J, Lafaix C. Unusual neurologic manifestations occurring during dengue fever infection.
American Journal of Tropical Medicine and Hygiene 48:793802, 1993.

14. Ramos C, Sanchez G, Pando RH, Baquera J, Hernandez D, Mota J, Ramos J, Flores A, Llausas E. Dengue virus in the brain of a fatal case of hemorrhagic dengue fever. Journal of Neurovirology 4:465-468, 1998.

15. Rico-Hesse R, Harrison LM, Salas RA, Tovar D, Nisalak A, Ramos C, Boshell J, Mesa MTR, Nogueira RMR, Rosa APAT. Origins of dengue type 2 associated with increased pathogenicity in the Americas. Virology 230:244-251, 1997.

16. Rosa APAT, Vasconcelos PFC, Rosa EST, Rodrigues SG, Mondet B, Cruz ACR, Souza MRS, Rosa JFST. Dengue epidemic in Belém, Pará, Brazil, 1996-97. Emerging Infectious Diseases 6:298-301, 2000.

17. Rosen L. The Emperor's new clothes revisited, or reflections on the pathogenesis of dengue hemorrhagic fever. American Journal of Tropical Medicine and Hygiene 26:337-343, 1977.

18. Row D, Weinstein P, Murray-Smith S. Dengue fever with encephalopathy in Australia. American Journal of Tropical Medicine and Hygiene 54:253-255, 1996.

19. Shope RE, Sather GE. Arboviruses. In: Lennette EH, Schmidt NJ (eds) Diagnostic procedures for viral, rickettsial and chlamydial infections. $5^{\text {th }}$ edition, American Public Health Association, Washington p. 767-814, 1979.

20. Sumarmo HW, Jahja E, Gubler DJ, Suharyono W, Sorensen K. Clinical observations on virologically confirmed fatal dengue infections Jakarta, Indonesia. Bulletin of World Health Organization 61:693-701, 1983.

21. Sumarmo HW, Wulur H, Jahja E, Gubler DJ, Sutomenggolo TS, Saroso JS. Encephalopathy associated with dengue infection. Lancet I:449-450, 1978.

22. Vasconcelos PFC, Rosa APAT, Coelho ICB, Menezes DB, Rosa EST, Rodrigues SG, Rosa JFST. Involvement of the central nervous system in dengue fever: three serologically confirmed cases from Fortaleza, Ceará, Brazil. Revista do Instituto de Medicina Tropical de São Paulo, 40:35-39, 1998.

23. Vasconcelos PFC, Rosa APAT, Pinheiro FP, Rodrigues SG, Rosa EST, Cruz ACR, Rosa JFST. Aedes aegypti, dengue and reurbanization of yellow fever in Brazil and other South American Countries - past and present and future perspectives. World Health Organization Dengue Bulletin 23:55-66, 1999. 